\title{
Red palm weevil (Rhynchophorus ferrugineus Olivier): Recent advances
}

\author{
F. Gonzalez ${ }^{1}$, S. Kharrat ${ }^{2}$, C. Rodríguez ${ }^{1}$, C. Calvo ${ }^{1}$ and A.C. Oehlschlager ${ }^{1}$ \\ (1) ChemTica Internacional S.A., Apdo. 640-3100, Heredia, Costa Rica, email: francisco_gonzalez@chemtica.com; \\ (2) Department of Life Sciences, University of Carthage, Zarzouna, Tunisia.
}

\begin{abstract}
Gonzalez, F., S. Kharrat, C. Rodríguez, C. Calvo and A.C. Oehlschlager. 2019. Red palm weevil (Rhynchophorus ferrugineus Olivier): Recent advances. Arab Journal of Plant Protection, 37(2): 178-187.

Red palm weevil (RPW, Rhynchophorus ferrugineus) is the most important pest of date and Canary palm in the Middle East, Europe and North Africa. An important management technique has been trapping using the male produced aggregation pheromone, a palm produced kairomone (usually ethyl acetate) and food. The latter needs replacement every 2-4 weeks to maintain good attraction to traps. The use of low service or serviceless traps is viewed by many as the next step in the evolution of the mass trapping technique. Recently a trap sold as the Electrap $^{\mathrm{TM}}$, has been introduced to the market as a dry, serviceless trap. Its alleged mechanism of action is based on the attraction of insects via electromagnetic radiation. According to the manufacturer, light emitted into the trap is focused into a resonance chamber containing pheromone and kairomone and from this chamber specific frequencies of electromagnetic radiation are emitted which contact the insect and result in its attraction to the trap. Generation of the attractive electromagnetic radiation is supposed to be due to mirrors on the internal sides of the chamber containing the pheromone and kairomone. In this study, we have examined the Electrap ${ }^{\mathrm{TM}}$ with and without mirrors in the chamber and compared the effectiveness of the Electrap ${ }^{\mathrm{TM}}$ vs the standard and modified bucket traps using $R$. palmarum as a surrogate organism. Our findings indicated that mirrors are not necessary for attraction of $R$. palmarum to the Electrap ${ }^{\mathrm{TM}}$ and that "serviceless" bucket traps are equally attractive. We also determined that the performance of the Electrap ${ }^{\mathrm{TM}}$ is due to retention of captured palm weevils by the bristle ring inside the conical entry point. Modification of side entry bucket traps by substitution of side entry by a conical entry point on the top results in better weevil retention. Top cone entry bucket traps retain water $3 X$ better than side entry bucket traps. Additionally, we also present data for an "attract and kill" formulation tested against RPW in Malaysian coconut. The attract and kill formulation reduced monitoring trap captures in the test site by over $95 \%$ from pre-application and is effective for at least 9 months. Both cases represent new insights and research avenues to develop better control of palm weevils.

Keywords: Conical traps, Electrap ${ }^{\mathrm{TM}}$, mass trapping, pheromones, serviceless traps, attract and kill.
\end{abstract}

\section{Introduction}

Coconut, oil, date and canary palms are of economic and cultural importance (Barlow et al., 2003; Chao and Krueger, 2007; Debmandal and Mandal, 2011). In the last century cultivation of these palms has become increasingly challenging due to the large areas devoted to their monoculture. Currently, there are roughly $1 \mathrm{M}$ hectares of date palm, around $14 \mathrm{M}$ hectares of coconut palm and $21 \mathrm{M}$ hectares of oil palm worldwide (FAOSTAT, 2018). These crops share weevils of the family Rhynchophoridae as common threat. Palm weevils are currently ranked as the most devastating insect pests to palms. This is due to the ability of larvae of this weevil family to develop and cause damage inside palm stem tissue (El-Juhany, 2010; GiblinDavis et al., 1996; Milosavljevic et al., 2018). Among these weevils, the red palm weevil Rhynchophorus ferrugineus Oliver (RPW) and the American palm weevil R. palmarum Linnaeus are the most serious threats to date and oil palm, respectively (Faleiro, 2006; Rochat et al., 1991). In addition to direct larval damage $R$. palmarum vectors the nematode responsible for the red ring disease (Gerber and GiblinDavis, 1990).

Before the mid 1990's management of these pests was based on insecticide spraying and injection often coupled with cutting of infested palms (Abozuhairah et al., 1996; Oehlschlager, 2006; Rodríguez et al., 2016). In the last two decades mass trapping using traps baited with male- produced pheromones in combination with food baits has evolved as a major component of most area-wide weevil management programs (Faleiro, 2006; Faleiro et al., 2011; Giblin-Davis et al., 1996; Oehlschlager, 2006; Rodríguez et al., 2016). In the Americas, side entry bucket traps with male-produced pheromone of $R$. palmarum and insecticidetreated sugarcane led to successful management of $R$. palmarum populations in Central America, leading to decreases of the vectored red ring disease of over $80 \%$ in 1 year in Costa Rica and 94\% in Honduras over 5 years (Oehlschlager et al., 1993, 2002; Rodríguez et al., 2016). These reductions were achieved in oil palm at very low trap densities that averaged 1 trap / 5 hectares (Rodríguez et al., 2016). The most effective trap for $R$. palmarum consists of a bucket trap with side entry containing a pheromone lure, fermenting food baits, the kairomone ethyl acetate (Chinchilla et al., 1995; Rodríguez et al., 2016), and sufficient insecticide to immobilize arriving weevils.

For $R$. ferrugineus, chemical analysis of male produced pheromone determined 4-methyl-5-nonanol (ferrugineol) as the aggregation pheromone of this species (Dembilio and Jaques, 2015; Hallet et al., 1993). Abozuhairah et al. (1996) showed increased attraction when combined with the minor pheromone component 4-methyl-5-nonanone at a ratio of 9:1. Further studies also determined higher captures when the pheromone is combined with food baits, especially fodder dates placed on black bucket traps (Abuaglala and AlDeeb, 2012). Furthermore, research carried out in the United 
Arabic Emirates (UAE) in 1997 and in Egypt in the same year demonstrated increased captures of $2.6 \mathrm{X}$ and $5 \mathrm{X}$ respectively, to traps baited with ethyl acetate in combination with the major and minor pheromone components of $R$. ferrugineus (Oehlschlager, 2006). It has also been determined that 1 to 10 traps per hectare are suitable for control of low and high infestations, respectively (Faleiro et al., 2011). A large study carried out in 10 commercial farms of the UAE demonstrated significant reductions of infested palm trees (ranging from 90.4 to $100 \%$ ) by using bucket traps with the pheromone ferrugineol and fodder dates as food bait (Kaakeh et al., 2001). Since then, the use this system has become a fundamental component of an integrated pest management strategy to control this pest, responsible for population reduction of up to $52 \%$ in date palms of the UAE (Abbas et al., 2006; Faleiro et al., 2011).

Despite the success of pheromone and food-based systems to mass trap weevils, their use has several practical constraints. For instance, food baits need to be replaced every 2-3 weeks (Fiaboe et al., 2011; Hallet et al., 1999). High temperatures cause water evaporation and hence, unless an insecticide is used, captured insects are not quickly killed and escape (Oehlschlager, 2006; Vacas et al., 2013). Servicing of traps has been the primary constraint in areawide mass trapping programs. A suggested alternative is the use of paste matrix formulations that release pheromone and contain contact insecticides capable of attracting and killing weevils (A\&K). Although promising results have been observed in Saudi Arabia (El-Shafie et al., 2011) and India (Gonzalez, 2018), this technology relies on pesticide, which most countries prefer not to use. After 7 years of trials there is no widespread use of the $\mathrm{A} \& \mathrm{~K}$ technique in palm and no registered commercial product.

Since mass trapping is conducted in the Americas against $R$. palmarum in oil palm, and these traps contain insecticide, escape is minimal (Oehlschlager, 2006; Rodríguez et al., 2016). In the Middle East and North Africa and Europe trapping for $R$. ferrugineus usually involves trapping without insecticide in which case escape from traps is expected to be higher. Recently, attention has turned to improvement of trap design to improve the efficiency of trapping programs. The goal is to develop a trap bait that does not need replacement and a trap that decreases escape (Al-Saroj et al., 2017). The first serviceless trap, the Electrap $^{\mathrm{TM}}$ (UAE FIRST, Abu Dhabi, UAE) was recently introduced into the commercial market in the Middle East (Porcella, 2013). This trap is claimed to function by allowing sunlight to enter the trap and penetrate an internal radiation chamber whose interior sides are covered in mirrors and into which pheromone and ethyl acetate are evaporated. According to the manufacturer vibrational radiation is emitted from the chamber which then is detected by the insect that is, in turn, attracted to the source of the radiation within the trap (Al-Saroj et al., 2017; Burr, 2002). Although the vibrational radiation theory has been disproven by overwhelming evidence of molecular interaction in insect olfaction (Antony et al, 2016, 2018; Block et al., 2015; Vosshall, 2015), Electrap ${ }^{\mathrm{TM}}$ was equivalent in capture to the standard side entry bucket trap used in area-wide Saudi Arabia for mass trapping $R$. ferrugineus and to a pheromone, kairomone and food baited Picusan ${ }^{\mathrm{TM}}$ trap (Al-Saroj et al., 2017; Dhouibi et al., 2017).

Since $R$. palmarum has been a good surrogate for $R$. ferrugineus in development of mass trapping techniques, and considering the contradicting alleged mechanism of the Electrap $^{\mathrm{TM}}$ we sought to understand the ability of the Electrap $^{\mathrm{TM}}$ to capture $R$. ferrugineus by studying its efficiency in capture of $R$ palmarum. We compared capture of $R$. palmarum in the Electrap ${ }^{\mathrm{TM}}$ baited with Rhyncholure ${ }^{\mathrm{TM}}$ (pheromone) and ethyl acetate (kairomone) dispensers inside the radiation chamber but where one set of Electraps ${ }^{\mathrm{TM}}$ contained mirrors and a second set that did not contain mirrors in the radiation chamber. The pheromone and kairomone dispensers were of the same size as those used in the Electrap during 2016 and 2017 and did not obstruct mirrors as per manufacturer's guidelines. We compared captures of $R$. palmarum obtained with these traps with those obtained using identical dispensers in a standard bucket trap modified for top cone entry. In a separate experiment, we compared the effectiveness of Electraps ${ }^{\mathrm{TM}}$ in which Rhyncholure $^{\mathrm{TM}}$ and ethyl acetate dispensers were placed in the radiation chamber vs outside the radiation chamber. We further compared the dry Electrap ${ }^{\mathrm{TM}}$ baited with Rhyncholure $^{\mathrm{TM}}$ and ethyl acetate dispensers to the standard bucket trap baited with food, the same pheromone and kairomone used for capture of $R$. palmarum and a bucket trap modified for top entry only also baited with food and the same pheromone and kairomone. We also compared the efficiency of the Electrap ${ }^{\mathrm{TM}}$ with and without the bristle ring at the top to determine how this feature affects retention efficiency. We further conducted experiments on retention of $R$. palmarum and water in standard bucket traps and bucket traps modified for top entry.

In an A\&K trial in Malaysian coconut, we tested Smart Ferrolure+ (Semiochemical Matrix Advanced Release Technology) paste for the control of $R$. ferrugineus in a coconut plantation.

\section{Materials and Methods}

\section{Study sites}

All experiments relating to trapping of $R$. palmarum were conducted within a 17,000 ha commercial oil palm plantation in Coto, in South Eastern Costa Rica. For each experiment, pre-evaluation determined the presence of $R$. palmarum. Normal practices of pruning, harvesting and phytosanitation were continued during the study. Per normal practice no insecticides were applied to control the weevils.

In the A\&K experiment, an experimental coconut palm plantation of 4 hectares located in the University of Kuala Perlis, Malaysia was used. Normal practices of pruning, harvesting and phytosanitation were continued during the study, and no insecticides were applied to control the weevils.

\section{Trapping experiments}

Standard bucket traps were 10 liter plastic buckets with four side entrances buried to the level of the entrance ports (Oehlschlager et al., 2002). Each trap contained 7 sugarcane halved sticks $(20 \mathrm{~cm})$ dipped in $0.1 \%$ Benfuracarb, a slow 
release dispenser containing the pheromone rhynchopherol (Rhyncolure, ${ }^{\mathrm{TM}}$ approx. $7 \mathrm{mg} /$ day, ChemTica Int., Costa Rica) and a slow release dispenser emitting ethyl acetate (20$40 \mathrm{mg} /$ day, ChemTica Int., Costa Rica) hung from the inside of the lid (Figure 1A). Electraps ${ }^{\mathrm{TM}}$ were baited with the same rhynchopherol and ethyl acetate lures that fit into the radiation chamber and obstructed no more than $4 \mathrm{~cm}^{2}$ of the side mirrors of the chamber. These dispensers were the same size and shape as the Ferrolure+ and ethyl acetate dispensers used in the Electraps ${ }^{\mathrm{TM}}$ when they were evaluated in Saudi Arabia for comparison against standard traps used in Saudi Arabian mass trapping programs against $R$. ferrugineus (AlSaroj et al., 2017). Both sets of lures were designed to function according to trap manufacturer's specifications inside the radiation chamber by obstructing as little of the mirrored surface as possible while providing efficacious release of the semiochemicals. A bucket trap was modified to contain the cone and disk portion of a Unitrap fit into an entrance hole in the center of the lid (Figure 1B). The cone was modified to have a bottom entry diameter of $5.5 \mathrm{~cm}$ and cut on the perimeter so that the rim rose no more than $0.5 \mathrm{~cm}$ above the lid surface. The first of these modifications was made so that the entry diameter would be close to that of the Electrap $^{\mathrm{TM}}$ while the second modification was to allow a low vertical barrier to entering weevils. Modified bucket traps were always buried to lid level to allow weevils to crawl into the trap. Standard bucket traps were always buried to the level of the side entry ports so that weevils that landed near the trap could easily crawl in. Electraps ${ }^{\mathrm{TM}}$ (Figure 1C). were used unmodified according to manufacturer's directions as well as at variance with the manufacturer's directions with pheromone and kairomone lures placed outside the radiation chamber, with mirrors removed and with bristle ring removed. Experiments were set up in a complete randomized block design with 50 meters between traps within a replicate and between replicates. Insects were counted and removed weekly and for multi-week experiments trap positions were re-randomized weekly. Retention of $R$. palmarum by the bristle rings at the top of the Electrap ${ }^{\mathrm{TM}}$ as well as retention experiments of the standard bucket trap and the bucket trap modified for top entry by addition of a Unitrap cone and disk to the lid of the bucket trap were determined by placing 10 freshly captured $R$. palmarum of mixed sex in a trap which was within a 2 M X 2 M X 2 m wire cage (outside in shade) and observing the proportion of $R$. palmarum that remained in a trap after $24 \mathrm{hrs}$. Similarly, we observed the changed in water content by weighting $1 \mathrm{~L}$ of water in standard bucket traps vs the modified lid traps at the beginning of the experiment and 24 hours later.

\section{Attract and kill experiment}

The experimental plot was a RPW infested 4 ha coconut planting in the field station of the University of Malaysia at Kuala Perlis, Malaysia containing 446 palms. Three weeks prior to the placement of A\&K formulation four bucket traps with pheromone (Ferrolure), kairomone (ethyl acetate), 4-6 sticks of $20 \mathrm{~cm}$ long sugarcane partially immersed in soapy water ( $1 \%$ laundry detergent) were distributed on the four sides of the 4 ha plot of RPW infested coconut (1 trap/hectare), and the populations were recorded weekly. Sugarcane was replaced every 2 weeks. The A\&K matrix consisted of an emulsified wax formulation of Ferrolure in combination with cypermethrin $\left(5 \%\right.$, Smart Ferrolure $\left.{ }^{\mathrm{TM}}\right)$. A\&K paste was applied during the late afternoon, to all palms in the plot at the rate of 2 dollops (of $3 \mathrm{~g}$ each) per tree on the North and South side of the stem of the palm at a height of $\sim 2$ meters, using a standard caulking gun modified to dispense the required quantity. This procedure was repeated 3 months after the first application. No application was performed elsewhere (traps or non-hosts). Monitoring traps were checked bi-weekly during 12 months after application.

\section{Statistical Analyses}

In the case of trapping tests, normality tests were carried out for each set of data. For all trials, pairwise comparisons were performed with Student T-Test. Test with multiple treatments were also analyzed with repeated measures ANOVA and LSD as posthoc. In case of not normally distributed data, we used Kruskall Wallis Test and the Dwass, Steel, Critchlow-Fligner Method for pairwise comparisons. In the case of the $\mathrm{A} \& \mathrm{~K}$ experiment a time series exploration analysis with an augmented DickeyFueller Test was performed to observe the trend in the plot receiving the A\&K application. A Wilcoxon Two Sample Test was also used to compare the average captures pre- and post- A\&K application. All analyses were carried out with SAS Studio 9.4 (SAS Inc., NC, USA).
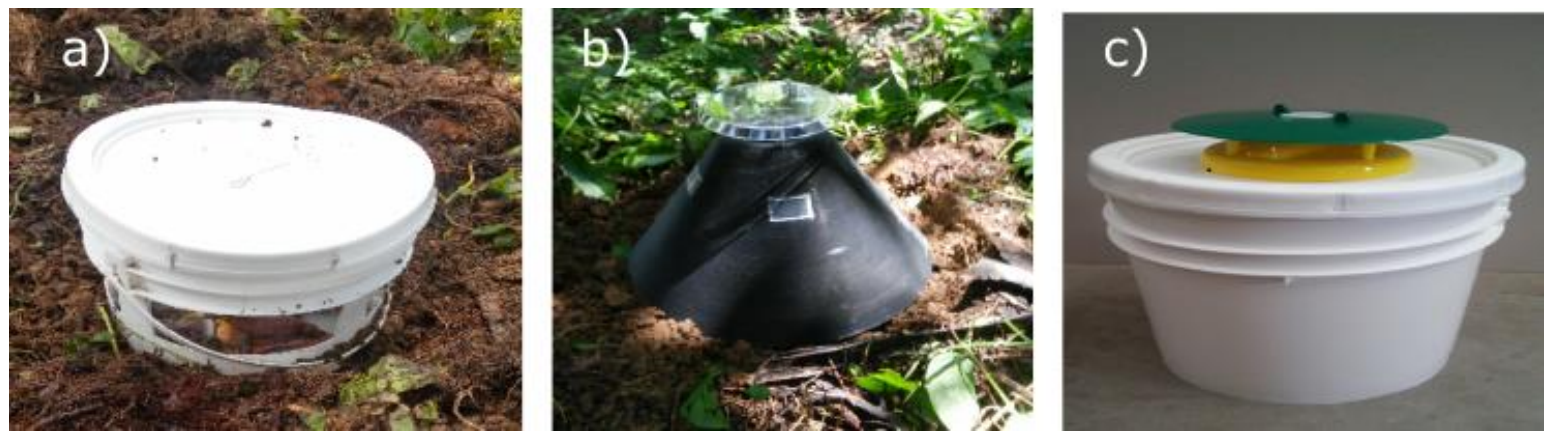

Figure 1. Different trap designs compared for mass trapping of weevils: (A) standard bucket trap with lateral entrances, (B) Electrap ${ }^{\mathrm{TM}}$ and (C) modified standard bucket trap with single cone entry point on lid. 


\section{Results}

\section{Trapping experiments}

A comparison of Electraps ${ }^{\mathrm{TM}}$ baited with Rhyncholure ${ }^{\mathrm{TM}}$ (pheromone) and ethyl acetate (kairomone) with and without mirrors in the radiation chamber revealed that Electraps ${ }^{\mathrm{TM}}$ with mirrors and those without mirrors functioned equally (Figure 2). This experiment also revealed significantly greater capture for a bucket trap modified for top cone entry baited additionally with sugarcane (Figure 2).

Comparison of Electraps ${ }^{\mathrm{TM}}$ in which Rhyncholure ${ }^{\mathrm{TM}}$ and ethyl acetate dispensers were placed inside the mirrored radiation chamber and outside the radiation chamber revealed that there is a benefit to placement of the dispensers in the chamber. When the dispensers are inside the chamber statistically more $R$. palmarum are captured than when the dispensers are placed outside the chamber (Figure 3).

Comparison of the standard side entry bucket trap with a bucket trap modified for top cone entry by addition of a Unitrap cone and disk revealed that the later performed significantly better than the standard bucket trap when baited with Rhyncholure ${ }^{\mathrm{TM}}$, ethyl acetate and sugarcane (Figure 4).

When sugarcane is omitted from the bait in the modified bucket trap it captured significantly less $R$. palmarum than either the standard bucket trap or the modified bucket trap containing sugarcane (Figure 4).

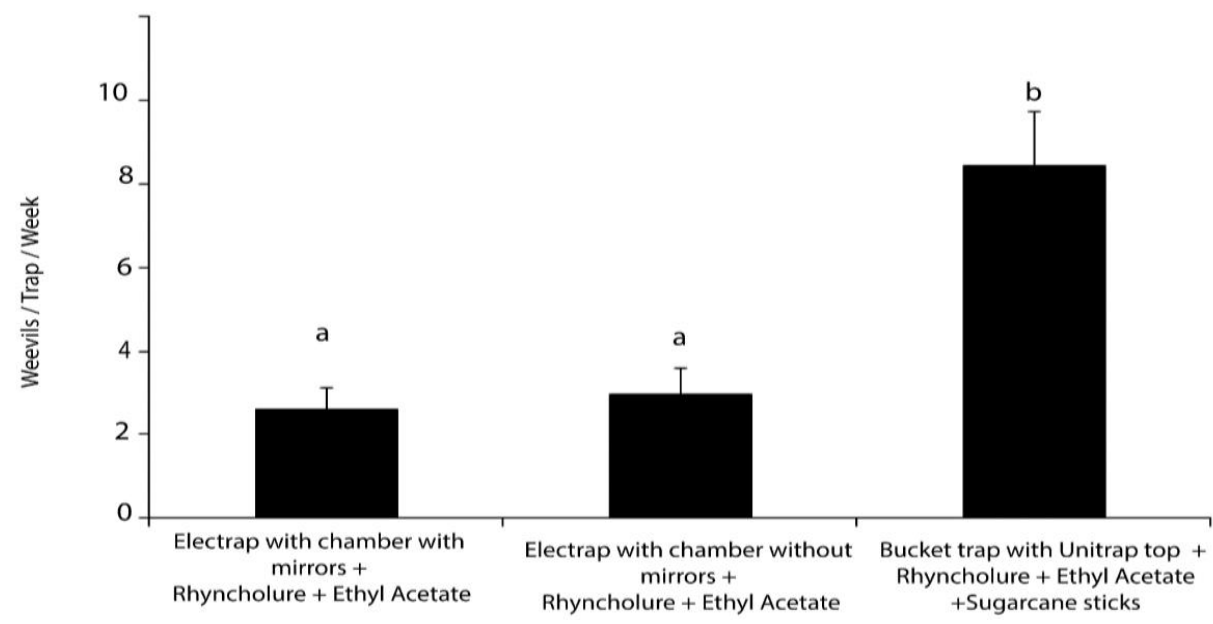

Figure 2. Average weekly captures of $R$. palmarum in Electrap ${ }^{\mathrm{TM}}$ with and without mirrors in internal emission chambers and bucket trap with Unitrap top with sugarcane. Experiment conducted in Palma Tica experimental farm, Coto 47, Costa Rica, July 11 to September 5, 2017. Insects counted, removed and trap positions re-randomized weekly. Statistically equivalent captures week to week throughout experimental period. Bars topped by different letters are statistically different by student T-test, $p<$ $0.05, \mathrm{n}=23$ and repeated measures ANOVA with LSD $p<0.05, \mathrm{n}=3 . . p<0.05, \mathrm{n}=3$.

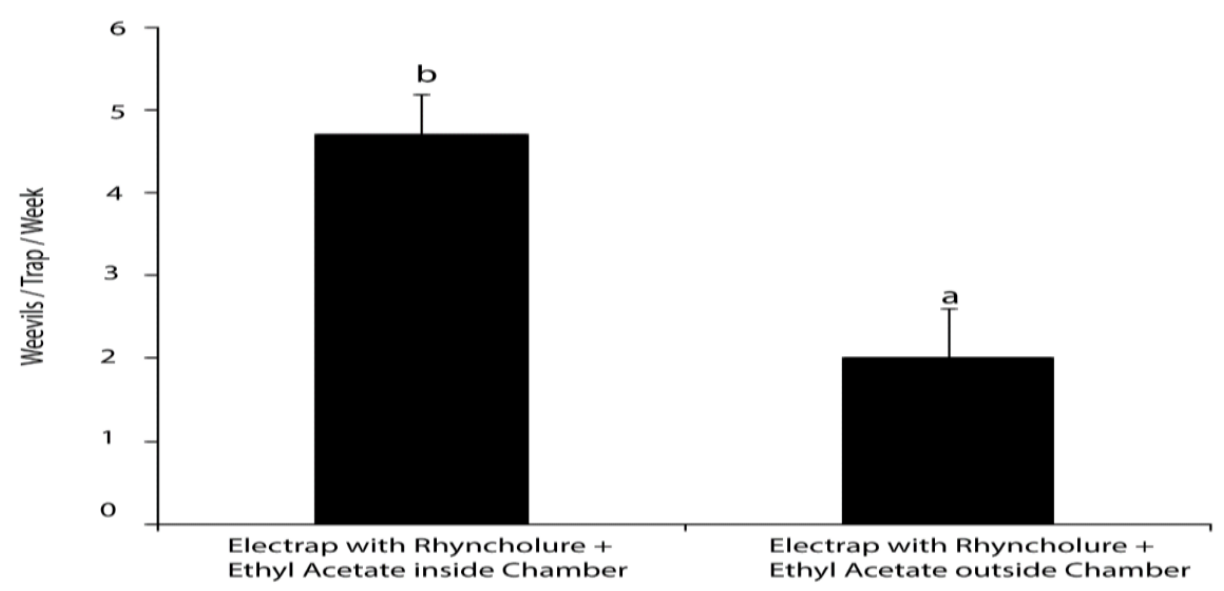

Figure 3. Average weekly capture of $R$. palmarum in Electraps ${ }^{\mathrm{TM}}$ in which Rhyncholure and ethyl acetate dispensers were placed inside or outside mirrored radiation chambers. Experiment conducted in Palma Tica experimental farm, Coto 47, Costa Rica, July 11 to August 11, 2017. Insects counted, removed and trap positions re-randomized weekly. Statistically equivalent captures week to week throughout experimental period. Bars topped by different letters are statistically different by student T-test, $p<$ $0.05, \mathrm{n}=10$. 
Retention experiments revealed that the presence of the bristle ring at the top of the Electrap ${ }^{\mathrm{TM}}$ resulted in an almost complete retention of $R$. palmarum within the trap over a 24 hour period while when the bristle ring was removed the number of escapees increased by $\sim 3 \mathrm{X}$ over the same time period. The traditional side entry bucket trap, was the trap type that allowed the highest number of weevils to escape, whereas the bucket trap modified for top cone entry was the best bucket trap for retaining $R$. palmarum (Figure 5). Water retention is also better in the bucket trap with Unitrap top. Over 24 hours the standard bucket losses up to 3 times more water than the modified bucket trap with Unitrap top (Figure $6)$.

\section{Attract and kill experiments}

During the first week of evaluation (prior A\&K treatment of palms) the average number of weevils captured per trap was 13.25. During the subsequent 2 weeks the average per trap decreased at a rate of approximately 2.75 less individuals per week. However, after the A\&K application RPW captures dropped from 7.75 to 1 in one week and followed a trend close to zero in the following weeks. During the next months from the first application RPW captures averaged 0.15 weevils per trap per week (Figure 7A). As expected, the comparison of captures pre- and post-application of A\&K showed a significant effect (Figure 7B).

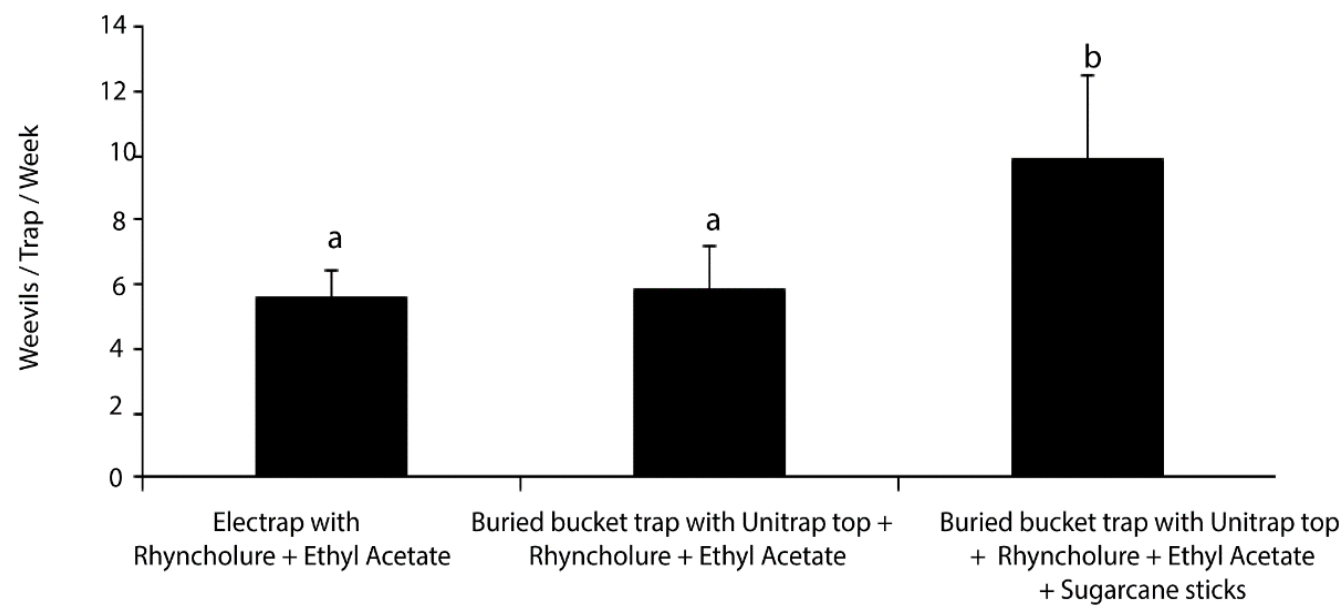

Figure 4. Capture or R. palmarum in different commercial traps, Electrap ${ }^{\mathrm{TM}}$, standard bucket trap with Unitrap top and standard bucket trap with sugarcane. Different letters above bars indicate captures significantly different by student $\mathrm{T}$-test, $p<0.05, \mathrm{n}=$ 7 and repeated measures ANOVA with LSD, $p<0.05, \mathrm{n}=3$. Test conducted in Palma Tica experimental farm Coto 47, Costa Rica, June 14-30, 2017.

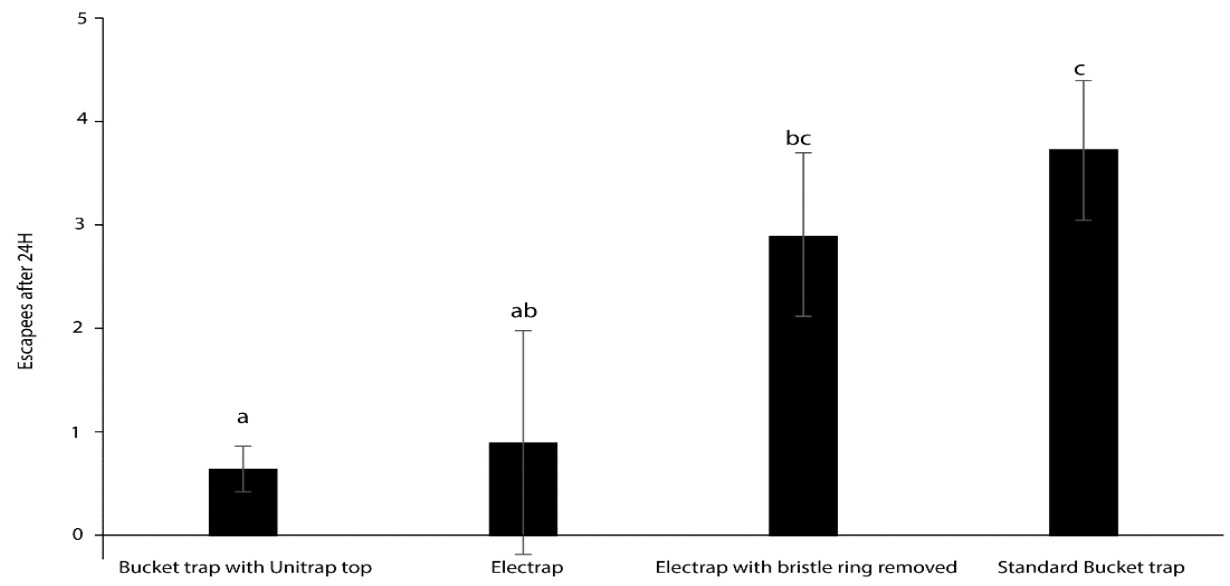

Figure 5. Average number of 10 R. palmarum escaping from different traps over 24 hr: Standard side entry bucket traps, Bucket traps with Unitrap top, Electrap ${ }^{\mathrm{TM}}$ and Electrap ${ }^{\mathrm{TM}}$ with bristle ring removed. Different letters above bars indicate significant differences between treatments analyzed by Kruskall-Wallis Test and contrasted by Dwass, Steel, Critchlow-Fligner Method, $p$ $<0.05, \mathrm{n}=10$. 


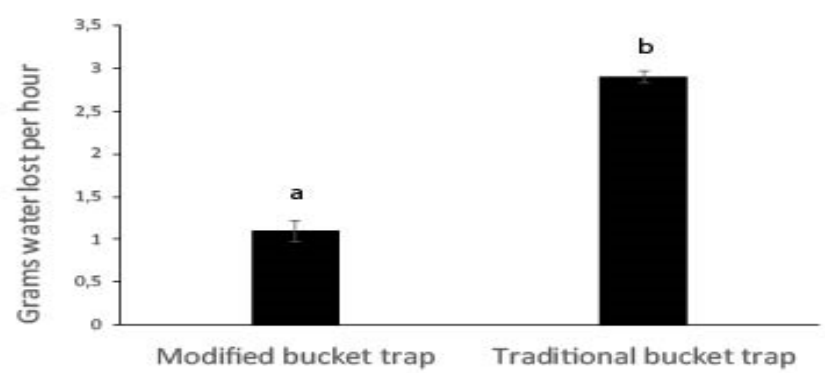

Figure 6. Average losses of grams of water per hour. Different letters above bars indicate significant differences between treatments analyzed by T-test, $p<0.05, \mathrm{n}=8$.

\section{Discussion}

The advertised mechanism of action of the Electraps ${ }^{\mathrm{TM}}$ is that semiochemicals such as Rhyncholure ${ }^{\mathrm{TM}}$ and ethyl acetate are energized by natural light to vibrate and that these vibrational frequencies are detected by insect antennae (Porcella, 2013). This theory was recognized during the 1960s and 1970s among some scientists. For instance, Callahan (1975) proposed that antennae act as resonators that detect wavelengths of infrared radiation of excited semiochemicals. Merely two years later, this theory was shown to conflict with basic physics (Diesendorf, 1977). In 2015, the radiation theory of olfaction was finally put to the rest when Block et al., (2015) showed that independent of the vibrational frequencies of molecules they are equally detected by odorant receptors as predicted by the Nobel Prize laureates (Buck and Axel, 1991). In the intervening half century since the proposal of the radiation theory of olfaction the basis for detection of odorants by insect antennae has been clearly established to be by molecular interaction (Andersson et al., 2015; Fleischer et al., 2017; Szyszka and Galizia, 2015; Voshall, 2015). Indeed, the very procedure of identification of pheromones such as 4-methyl-5-nonanol, the pheromone of $R$. ferrugineus, involves electroantennal detection in which the antennae are exposed to the effluent of a gas chromatograph and exhibit a specific response to the effluent when the pheromone is eluted. Recently, Antony et al. (2016, 2018) provided clear genetic evidence for the molecular basis of detection of the pheromone of $R$. ferrugineus by its antennae. As our first experiment showed (Figure 2), the present results provide field evidence that the mirrors in the "Internal Emission Chamber" may be removed without impairing the functioning of the Electrap. ${ }^{\mathrm{TM}}$.

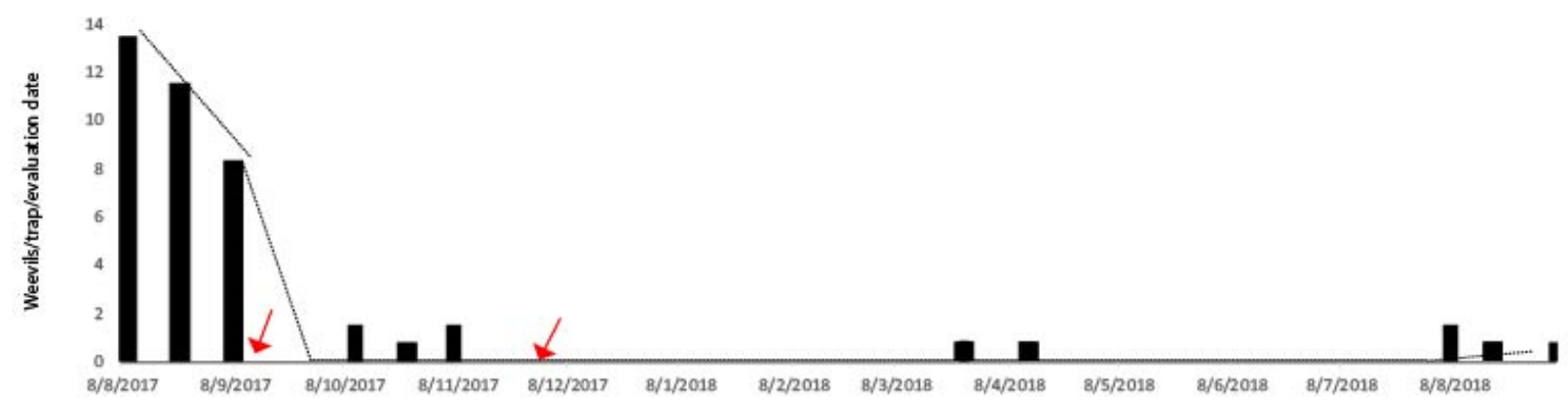

A)

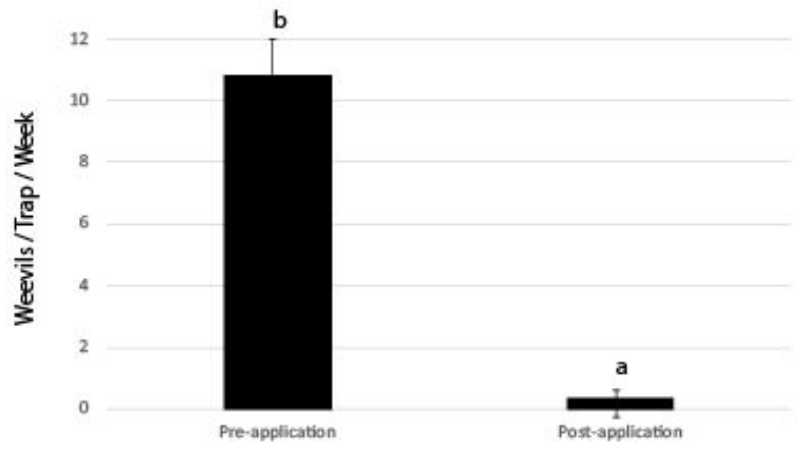

B)

Figure 7. RPW captures in 4 traps placed on the edges of 4 ha of coconut palm in which Smart Ferrolure was applied. (A) Average captures per week per trap: arrows indicated dates at which Smart Ferrolure ${ }^{\mathrm{TM}}$ was applied. Grey dotted line indicates trend. Time series analysis revealed stationary trend close to zero during the whole duration of the experiment (Augmented Dickey-Fuller Unit Root tests, $p<0.001$ ). (B) Comparison of average captures per trap prior and after A\&K application (Wilcoxon Two Sample Test, $p<0.05$ ). 
In combination with the results shown in Figure 2 we interpret the results in Figure 3 as being due to more restricted emission of semiochemical vapors from the chamber than from the trap resulting in a more constant release. This might be expected to result in higher capture due to higher release of attractants in the morning hours when a higher proportion of $R$. palmarum flight occurs. The reasoning is that as the trap warms in the morning hours the vapors already in the radiation chamber are released in higher amounts than vapors from the dispensers outside the chamber. Therefore, our results indicate that the chamber in the Electrap ${ }^{\mathrm{TM}}$ may contribute better captures, but as demonstrated, not because of the mirrors.

Since traps that have cone entry such as the Electrap ${ }^{\mathrm{TM}}$ appear to work well in retaining arriving $R$. palmarum, we examined a modification of the standard bucket trap in which the side entry ports were not present and the lid was fitted with a cone entry port constructed from a cone and disk from a standard Unitrap (Figure 4). This result is expected based on repetitive demonstration that addition of food baits increases weevil attraction (Haris et al., 2014; Jaffé et al., 1993; Kaakeh et al., 2001; Oehlschlager et al., 1993; Rochat et al., 2000)

An additional advantage of the modified bucket trap with Unitrap top is in its ability to retain $R$. palmarum. Within 24 hours almost $40 \%$ of $R$. palmarum in standard side entry bucket traps containing sugarcane escaped (Figure 5). By comparison $R$. palmarum are almost completely retained over 24 hours in modified top cone entry bucket traps. Retention experiments also revealed that the presence of the bristle ring at the top of the Electrap ${ }^{\mathrm{TM}}$ resulted in an almost complete retention of $R$. palmarum within the trap over a 24hour period. When the bristle ring was removed around $30 \%$ escaped over the same time period (Figure 5). Thus, the bristle ring is responsible for substantially increasing retention of $R$. palmarum in the trap and may explain why this trap shows captures equivalent to the standard Saudi Arabian side entry bucket trap for $R$. ferrugineus (Al-Saroj et al., 2017). In addition, the modified bucket retains much water and therefore will require less servicing than the standard bucket trap with side entry (Figure 6).

When it comes to the application of A\&K paste for the control of RPW in a coconut plantation in Malaysia, it is clear that the A\&K matrix had a fast knock down effect on the population (Figure 7). This effect lasted for a whole year, even when the application was performed only twice during the initial three months.

\section{Conclusions}

Palm weevils can be controlled with mass trapping techniques that combine pheromones and kairomones. However, the costs involved in servicing significantly increase costs of this technique for area-wide use. Serviceless traps are an attractive option. The first serviceless trap to be marketed, the Electrap ${ }^{\mathrm{TM}}$, appears to function on the same principle as most other insect traps. That is, by emitting attractive vapors that are detected by the target insect and induce the latter to approach and enter the trap. Since mirrors are not necessary for functioning of the Electrap ${ }^{\mathrm{TM}}$ but placement of lures in the resonance chamber leads to increased capture it would be good to investigate large long-lived lures in the Electrap ${ }^{\mathrm{TM}}$ to determine how long efficient capture can be achieved. The lower capture in serviceless traps compared to bucket traps containing pheromone, kairomone and food could be compensated by using increased numbers of serviceless traps. Modification of bucket traps for top cone entry provides an inexpensive alternative to both Picusan ${ }^{\mathrm{TM}}$ and Electrap ${ }^{\mathrm{TM}}$ designs which both cost more than $\$ 10$ USD.

Attract and kill technology appears to be a good option for rapid knockdown of RPW populations. The extended period of very low captures in monitoring traps surrounding the plot in which A\&K was applied indicate that both attraction and killing is occurring nearly a year after application. Since A\&K is more expensive to apply than setting traps the longevity of formulations is important.

\section{Acknowledgements}

We thank Palma Tica for allowing us to perform field experiments in their commercial plantations. Similarly, we thank the University of Malaysia at Kuala Perlis and the personnel of Sime Darby Plantation for their hard work monitoring the experiment. We also like to thank UAE FIRST for selling us the Electrap

$$
\begin{aligned}
& \text { الملخص } \\
& \text { غونزالز، فرانسيسو، سيّدة خراط، كارلوس رودريغوز، كارولينا كالقو وكان أوهلشلاجر. 2019. سوسة النخيل الحمراء Rhynchophorus. } \\
& \text { ferrugineus Olivier: آخر التظورات. مجلة وقاية النبات العربية، 37(2): 187-178. } \\
& \text { تعدّ سو سة النخيل الحمر اء (RPW) (Rhynchophorus ferrugineus Olivier) أهمّ الآفات التي تصيب نخيل التّرر و الكناري في منطقة الشرق } \\
& \text { الأوسط و أوروبا وشمال إفريقيا. تمّ اعتماد الاصطياد كتقنية مهمة لإدارة الآفة باستخدام: الفيرمون التجميعي الذي تفرزه الذكور، كيرمون منتج من }
\end{aligned}
$$

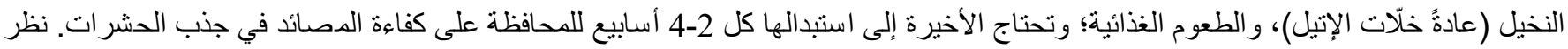

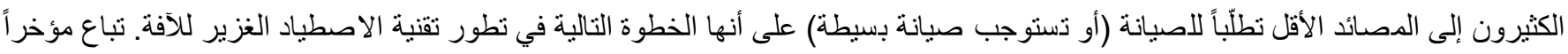

$$
\begin{aligned}
& \text { مصبدة تحت مسمّى "إلكتر ابTM" و التي يجري تسويقها كمصيدة جافة تسـتوجب صيانة بسيطة؛ وتستتد آلية عملها المزعومة على جذب الحشرات }
\end{aligned}
$$

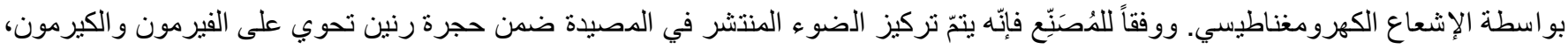

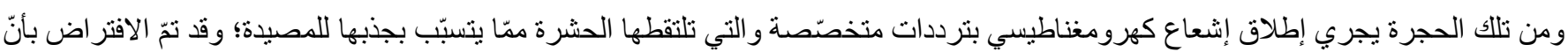


توليد الإشـاع الكهرومغناطيسي الجاذب يعزى إلى وجود مر ايا في الجو انب الداخلية للحجرة التي تحوي على الفيرمون والكيرمون. قمنا هنا باختبار

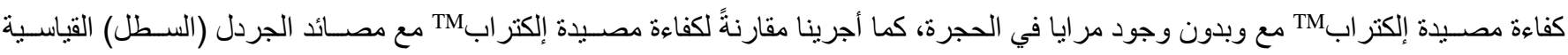

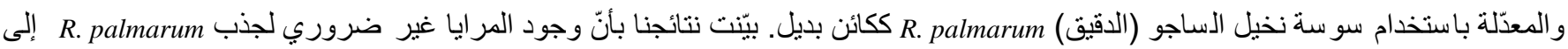

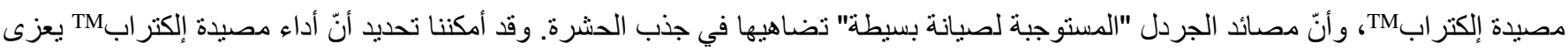
إلى احتفاظها بحشر ات سو سة النخيل الملتقطة بو ساطة حلقة الشعيرات الخشنة الموجودة داخل فتحة الدخول المخروطية. و إنّ تعديل مصائد الجردل ذات المدخل الجانبي باستبدال مدخلها الجانبي بمدخل آخر مخروطي الشكل يتموضـع أعلى المصيدة يحقّ نتائج أفضل بالاحتفاظ بحشر ات السوس. كما أن مصائد الجردل ذات المدخل المخروطي العلوي تحتفظ بالماء على نحوٍ أفضل بثلاثة أضعاف مما هو عليه الحال في تللك المصائد ذات المدخل بهل الجانبي. وفوق ذللك، نقدّم أيضـاً بياناتٍ لمستحضـر اتٍ تقنية "الجذب و القتل" والتي اختبرت على أشجار نخيل جوز الهند الماليزي إزاء سوسـة النخيل

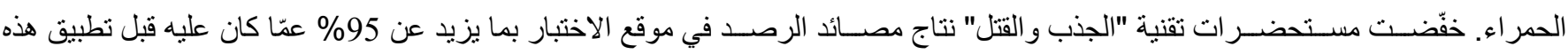
المعاملة، والتي استمرت فاعليتها لما لا يقلّ عن 9 أثهر ـ تقدّم كلتا الحالتين آفاقاً جديدةً ومحاور بحثية لتطوير مكافحةٍ أفضل لحشر ات سوس النخيل. كلمات مفتاحية: مصائد مخروطية، إلكتر ابدM، الاصطياد الغزير ، فيرمونات، المصائد الأقل تطلّباً للصيانة، الجذب و القتل.

\section{References}

Abbas, M.S.T., S.B. Hanounik, A.S. Shahdad and S.A. Ai-Bagham. 2006. Aggregation pheromone traps, a major component of IPM strategy for the red palm weevil, Rhynchophorus ferrugineus in date palms (Coleoptera: Curculionidae). Journal of Pest Science, 79: 69-73. https://doi.org/10.1007/s10340-005-0113-6

Abozuhairah, RA., P.S.P.V. Vidyasagar and V.A. Abraham. 1996. Integrated management of red palm weevil Rhynchophorus ferrugineus in date palm plantations of the Kingdom of Saudi Arabia. 3 Proceedings, XX Int Congress of Entomology, August 25-30, Firenze, Italy Contents described in Oehlschlager AC (2007) Optimizing trapping of palm weevils and beetles. Acta Horticulturae, 15: 347-368.

Abraham, V.A., M.A. Shuaibi, J.R. Faleiro, R.A. Abozuhairah and P.S. Vidyasagar. 1998. An integrated management approach for red palm weevil Rhynchophorus ferrugineus Oliv. A key pest of date palm in the Middle East. Journal of Agricultural and Marine Sciences, 3: 77-83. https://doi.org/10.24200/jams.vol3iss1pp77-83

Abuaglala, A. snd M.A. Al-Deeb. 2012. Effect of bait quantity and trap color on the trapping efficacy of the pheromone trap for the red palm weevil, Rhynchophorus ferrugineus. Journal of Insect Science, 12: 1-6. https://doi.org/10.1673/031.012.12002

Al-Saroj, S., E. Al-Abdallah, A. Al-Shawaf, A. AlDandan, I. Al-Abdullah, A. Al-shagag, Y. Al-fehaid, A. Abdallah and J. Faleiro. 2017. Efficacy of bait free pheromone trap (Electrap ${ }^{\mathrm{TM}}$ ) for management of red palm weevil, Rhynchophorus ferrugineus (Olivier) (Coleoptera: Curculionidae). Pest Management in Horticultural Ecosystems, 23: 55-59

Andersson, M.N., C. Löfstedt, and R.D. Newcomb. 2015. Insect olfaction and the evolution of receptor tuning. Frontiers in Ecology and Evolution, 3: 1-13. https://doi.org/10.3389/fevo.2015.00053

Antony, B., A. Soffan, J. Jakše, M.M. Abdelazim, S.A. Aldosari, A.S. Aldawood and A. Pain. 2016. Identification of the genes involved in odorant reception and detection in the palm weevil Rhynchophorus ferrugineus, an important quarantine pest, by antennal transcriptome analysis. BMC Genomics, 17: 69. https://doi.org/10.1186/s12864-016-2362-6

Antony, B., J. Johny and S.A. Aldosari. 2018. Silencing the Odorant Binding Protein RferOBP1768 Reduces the Strong Preference of Palm Weevil for the Major Aggregation Pheromone Compound Ferrugineol. Frontiers in Physiology, 9: 252. https://doi.org/10.3389/fphys.2018.00252

Barlow, C., Z. Zen and R. Gondowarsito. 2003. The Indonesian oil palm industry. Oil Palm Industry Economic Journal, 3: 8-15.

Block, E., S. Jang, H. Matsunami, S. Sekharan, B. Dethier, M.Z. Ertem, S. Gundala, Y. Pan, S. Li, Z. Li and S.N. Lodge. 2015. Implausibility of the vibrational theory of olfaction. Proceedings of the National Academy of Sciences, 112: E2766-E2774.

Buck, L. and R. Axel. 1991. A novel multigene family may encode odorant receptors: a molecular basis for odor recognition. Cell, 65: 175-187. https://doi.org/10.1016/0092-8674(91)90418-x

Burr, C. 2002. The Emperor of Scent. Random House, New York

Callahan, P.S. 1975. Insect antennae with special reference to the mechanism of scent detection and the evolution of the sensilla. International Journal of Insect Morphology and Embryology, 4: 381-430. https://doi.org/10.1016/0020-7322(75)90038-0

Chao, C.T. and R.R. Krueger. 2007. The date palm (Phoenix dactylifera L.): overview of biology, uses, and cultivation. Hortscience, 42: 1077-1082. https://doi.org/10.21273/hortsci.42.5.1077

Chinchilla, C.M., L.M. González and A.C. Oehlschlager. 1995. Optimization of a pheromone-baited trap for the American palm weevil Rhynchophorus palmarum (L). In PORIM International Palm Oil Congress: Update and vision September Kuala Lumpur, Malaysia (No. L-0314). PORIM. 
Debmandal, M. and S. Mandal. 2011. Coconut (Cocos nucifera L.: Arecaceae): in health promotion and disease prevention. Asian Pacific Journal of Tropical Medicine, 4: 241-247. https://doi.org/10.1016/s1995-7645(11)60078-3

Dembilio, Ó. and J.A. Jaques. 2015. Biology and management of red palm weevil. Pages 13-36. In: Sustainable Pest Management in Date Palm: Current Status and Emerging Challenges. W. Wakil, J. Romeno Faleiro and T.A. Miller (eds.). Springer International Publishing. https://doi.org/10.1007/978-3-319-24397-9

Dhouibi, M.H., N.C.I.B. Mouna and C. Hatem. 2017. Effect of Trap Size and Pheromone Capsule Types on the Trapping Efficacy for the Red Palm Weevil (Rhynchophorus ferrugineus). International Journal of Agriculture Innovations and Research, 5: 2319-1473.

Diesendorf, M. 1977. Insect sensilla as dielectric aerials for scent detection?: Comments on a review by PS Callahan. International Journal of Insect Morphology and Embryology, 6: 105-109. https://doi.org/10.1016/0020-7322(77)90015-0

EI-Juhany, L.I. 2010. Degradation of date palm trees and date production in Arab countries: causes and potential rehabilitation. Australian Journal of Basic and Applied Sciences, 4: 3998-4010.

El-Shafie, H.A.F., J.R. Faleiro, A.H. Al-Abbad, L. Stoltman and A. Mafra-Neto. 2011. Bait-free attract and kill technology (Hook ${ }^{\mathrm{TM}} \mathrm{RPW}$ ) to suppress red palm weevil, Rhynchophorus ferrugineus (Coleoptera: Curculionidae) in date palm. Florida Entomologist, 94: 774-778. https://doi.org/10.1653/024.094.0407

Faleiro, J.R. 2006. A review of the issues and management of the red palm weevil Rhynchophorus ferrugineus (Coleoptera: Rhynchophoridae) in coconut and date palm during the last one hundred years. International Journal of Tropical Insect Science, 26: 135-154. https://doi.org/10.1079/IJT2006113

Faleiro, J.R., M.A. El-Saad and A.H. Al-Abbad. 2011. Pheromone trap density to mass trap Rhynchophorus ferrugineus (Coleoptera: Curculionidae/ Rhynchophoridae/ Dryophthoridae) in date plantations of Saudi Arabia. International Journal of Tropical Insect Science, 3: 175-77. https://doi.org/10.1017/s1742758411000099

FAO. 2017. Report of the Scientific Consultation and Highlevel Meeting on Red Palm Weevil Management.

Fiaboe, K.K.M., R.W. Mankin, A.L. Roda, M.T.K. Kairo and C. Johanns. 2011. Pheromone-food-bait trap and acoustic surveys of Rhynchophorus ferrugineus (Coleoptera: Curculionidae) in Curacao. Florida Entomologist, 94: 766-773. https://doi.org/10.1653/024.094.0406

Fleischer, J., P. Pregitzer, H. Breer. and J. Krieger. 2017. Access to the odor world: olfactory receptors and their role for signal transduction in insects. Cellular and Molecular Life Sciences, 75: 485-508. https://doi.org/10.1007/s00018-017-2627-5

Gerber, K. and R.M. Giblin-Davis. 1990. Association of the red ring nematode and other nematode species with the palm weevil, Rhynchophorus palmarum. Journal of Nematology, 22: 143.

Giblin-Davis, R.M., A.C. Oehlschlager, A. Perez, G. Gries, R. Gries, T.J. Weissling, C.M. Chinchilla, J.E. Peña, R.H. Hallett, Jr. Pierce and L.M. Gonzalez. 1996. Chemical and behavioral ecology of palm weevils (Curculionidae: Rhynchophorinae). Florida Entomologist, 79: 53-167.

Gonzalez, F. 2018. The use of Rhynchphorus ferrugineus through two different methods: ChemTica Internacional S.A. experiences. In: VI International Date Palm Conference, Abu Dhabi, UAE.

Hallett, R.H., G. Gries, R. Gries, J.H. Borden, E. Czyzewska, A.C. Oehlschlager, H.D. Pierce, N.P.D. Angerilli and A. Rauf. 1993. Aggregation pheromones of two Asian palm weevils, Rhynchophorus ferrugineus and $R$. vulneratus. Naturwissenschaften, 80: 328-331.

Hallett, R.H., A.C. Oehlschlager and J.H. Borden. 1999. Pheromone trapping protocols for the Asian palm weevil, Rhynchophorus ferrugineus (Coleoptera: Curculionidae). International Journal of Pest Management, 45: 231-237. https://doi.org/10.1080/096708799227842

Haris, M.H., M.L.S. Nang, T.S. Chuah and A.A. Wahizatul. 2014. The efficacy of synthetic food baits in capturing red palm weevil, Rhynchophorus ferrugineus (Coleoptera: Curculionidae) in campus area of Universiti Malaysia Terengganu. Serangga, 19: 19-35.

Jaffé, K., P. Sánchez, H. Cerda, J.V. Hernández, R. Jaffé, N. Urdaneta, G. Guerra, R. Martínez and Miras, B. 1993. Chemical ecology of the palm weevil Rhynchophorus palmarum (L.) (Coleoptera: Curculionidae): Attraction to host plants and to a maleproduced aggregation pheromone. Journal of Chemical Ecology, 19: 1703-1720.

Kaakeh, W., F. El-Ezaby, M.M. Aboul-Nour and A.A. Khamis. 2001. Management of the red palm weevil, Rhynchophorus ferrugineus Oliv., by a pheromone/food-based trapping system. Pages 325343. In: Second International Date Palm Conference, Al-Ain, UAE.

Milosavljević, I., H.A. El-Shafie, J.R. Faleiro, C.D. Hoddle, M. Lewis and M.S. Hoddle. 2018. Palmageddon: the wasting of ornamental palms by invasive palm weevils, Rhynchophorus spp. Journal of Pest Science, 92: 143-156. https://doi.org/10.1007/s10340-018-1044-3

Oehlschlager, A.C., C. Chinchilla, G. Castillo and L. Gonzalez. 2002. Control of red ring disease by mass trapping of Rhynchophorus palmarum (Coleoptera: Curculionidae). Florida Entomologist, 85: 507-513. https://doi.org/10.1653/00154040(2002)085[0507:corrdb]2.0.co;2

Oehlschlager, A.C., C.M. Chinchilla, L.M. Gonzalez, L.F. Jiron, R. Mexon and B. Morgan. 1993. Development of a pheromone-based trapping system for Rhynchophorus palmarum (Coleoptera: Curculionidae). Journal of Economic Entomology, 86: 1381-1392. 
Oehlschlager, C. 2006. Optimizing trapping of palm weevils and beetles. Pages 347-368. In: $3^{\text {rd }}$ International Date Palm Conference, Abu-Dhabi, UAE.

Porcella, L. 2013. Electromagnetic Communication and Olfaction in Insects - Progresses in Studies and Applications on RPW Plague, 11 pp.

Rochat, D., C. Malosse, M. Lettere, P.H. Ducrot, P. Zagatti, M. Renou and C. Descoins. 1991. Maleproduced aggregation pheromone of the American palm weevil, Rhynchophorus palmarum (L.) (Coleoptera, Curculionidae): Collection, identification, electrophysiogical activity, and laboratory bioassay. Journal of Chemical Ecology, 17: 2127-2141. https://doi.org/10.1007/BF00987996

Rochat, D., P. Nagnan-Le Meillour, J.R. Esteban-Duran, C. Malosse, B. Perthuis, J.P. Morin and C. Descoins. 2000. Identification of pheromone synergists in American palm weevil, Rhynchophorus palmarum, and attraction of related Dynamis borassi. Journal of Chemical Ecology, 26:155-187. https://doi.org/10.1023/A:1005497613214

Rodríguez, C., A.C. Oehlschlager and C.M. Chinchilla, 2016. Examination of critical components of Rhynchophorus palmarum pheromone traps. ASD Oil Palm Papers, 46: 15.

Szyszka, P. and C.G. Galizia. 2015. Olfaction in insects. Pages 531-546. In: Handbook of Olfaction and Gustation.

Vacas, S., J. Primo and V. Navarro-Llopis. 2013. Advances in the use of trapping systems for Rhynchophorus ferrugineus (Coleoptera: Curculionidae): traps and attractants. Journal of Economic Entomology, 106: 1739-1746. https://doi.org/10.1603/EC13105

Vosshall, L.B. 2015. Laying a controversial smell theory to rest. Proceedings of the National Academy of Sciences, 112: 6525-6526. https://doi.org/10.1073/pnas.1507103112 